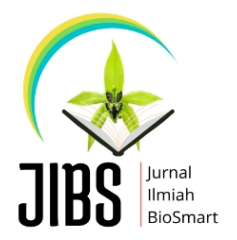

JURNAL ILMIAH BIOSMART (JIBS)

Volume 1, Nomor 1

p-ISSN: 2356-1823

https://jurnal.fkip.unmul.ac.id/index.php/biosmart

\title{
Analisis Tingkat Literasi Lingkungan Mahasiswa FKIP Universitas Mulawarman Dengan Transformasi Skor Nela (National Environmental Literacy Assessment)
}

\author{
Ruqoyyah Nasution \\ Prodi Pendidikan Biologi Fakultas Keguruan Dan Ilmu Pendidikan Universitas Mulawarman, \\ Samarinda, email : oya_nasution@yahoo.co.id
}

\begin{abstract}
There are so many natural resources in Indonesia, one of which is natural resources in the form of coal. East Kalimantan is one of the provinces with abundant coal resources. Communities and companies use coal to make coal in East Kalimantan a source of income. Coal not only has a positive impact but also has a negative impact, one of which is the remaining coal excavation in the form of giant pools that become Acid Mine Drainage. This is a special concern for researchers to know awareness of the environment by looking at the level of Environmental Literacy of the people of East Kalimantan. Environment, especially students of Mathematics and Natural Sciences FKIP UNMUL. The method in this research is descriptive, with an instrument in the form of an environmental literacy test adapted and modified from the Middle Schools Environmental Literacy Survey / Instrument (MSELS / I). The analysis of the level of environmental literacy was transformed using scores from the NELA (National Environmental Literacy Assessment). In NELA's assessment, there are four domains, namely 1). knowledge; 2). Cognitive skills; 3). Attitude; and 4). Behavior. The results showed that the environmental literacy of FKIP students was in the "Medium" category. From these categories, it can be used as a basis for improving environmental literacy of FKIP Mulawarman University students.
\end{abstract}

Key words: Environmental Literacy, NELA scores transformation

\begin{abstract}
Abstrak Sumber daya alam Indonesia begitu banyak salah satunya adalah sumber daya alam berupa batubara. Kalimantan Timur merupakan salah satu provinsi dengan sumber batubara yang melimpah. Masyarakat dan perusahaan menjadikan batubara menjadikan batubara di Kalimantan Timur sebagai sumber pendapatan. Batubara tidak hanya memberikan dampak positif tapi juga memiliki dampak negatif salah satunya sisa galian batubara yang berupa kolam-kolam raksasa yang menjadi Drainase Tambang Asam (Acid Mine Drainage). Hal ini menjadi perhatian khusus bagi peneliti untuk mengetahui kesadaran terhadap lingkungan dengan melihat tingkat Literasi Lingkungan masyarakat Kalimantan timur Lingkungan khususnya Mahasiswa pendidikan MIPA FKIP UNMUL. Metode dalam penelitian ini adalah Deskriptif, dengan instrument berupa tes literasi lingkungan yang diadapatasi dan dimodifikasi dari Middle Schools Environmental Literacy Survey/ Instrument (MSELS/ I). Analisis tingkat literasi lingkungan ditransformasikan menggukan pensekoran dari NELA (National Environmental Literacy Assessmen). Dalam pensekoran NELA terdapat empat domain yaitu 1). pengetahuan; 2). Keterampilan kognitif; 3). Sikap; dan 4). Perilaku. Hasil penelitian memperlihatkan bahwa literasi lingkungan mahasiswa FKIP ada pada katagori "Sedang". Dari katagori tersebut dapat digunakan sebagai dasar untuk meningkatkan literasi lingkungan mahasiswa FKIP Universitas Mulawarman.
\end{abstract}

Kata kunci : Literasi lingkungan, Tranformasi skor NELA 


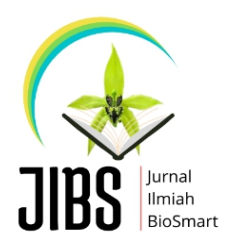

JURNAL ILMIAH BIOSMART (JIBS)

Volume 1, Nomor 1

p-ISSN: 2356-1823

https://jurnal.fkip.unmul.ac.id/index.php/biosmart

Penerbit

Program Studi Pendidikan Biologi, Fakultas Keguruan dan Ilmu Pendidikan, Universitas Mulwarman, Samarinda, Kalimantan Timur, Indonesia

(c) (1) ()

This Jurnal Ilmiah Biosmart (JIBS) is licensed under a CC BY-SA (Creative Commons AttributionShareAlike 4.0 International License)

\section{PENDAHULUAN}

Indonesia adalah negara dengan sumber daya alam yang melimpah, sumber daya alam tersebut berupa minyak bumi, gas, batubara dan hutan yang sangat luas. Keberadaan sumberdaya alam tersebut juga tersebar di Kalimantan Timur. Raven et al., (2013) menyatakan bahwa salah satu sumber daya alam yang penting dibumi adalah batubara. Dampak positif dari adanya pertambangan barubara adalah kesejahteraan masyarakat di wilayah tersebut. Kesejahteraan tersebut secara umum terlihat meningkat dari keberadaan perusahaan-perusahaan, yang telah mampu mendorong dan menggerakkan ekonomi masyarakat, struktur sosial di masyarakat juga mengalami perubahan. Hal lain yang juga tidak terabaikan adalah dampak negatif yaitu berupa kerusakan lingkungan. Kerusakan tersebut salah satunya adalah kerusakan yang diakibatkan oleh pertambangan batubara. Pada area pembakaran menyisakan limbah sisa pembakaran sedangkan pada area pertambagan menyisakan lubang-lubang raksasa sisa galian batubara, serta hamparan alam yang rusak karena dijadikan lokasi pertambangan. Bekas lubang galian batubara yang telah dikeruk habis berubah menjadi Drainase Tambang Asam (Acid Mine Drainage) yang sering berbentuk danau dan kolam raksasa.

Kegiatan berupa pertambangan tidak dapat dipungkiri dapat menyebabkan menyebabkan penurunan kualitas lingkungan berupa pencemaran serta masalahmasalah lingkungan. Untuk mengendalikan kerusakan lingkungan yang disebabkan oleh aktivitas perusahaan tambang batubara tersebut maka diperlukan kontrol yang kuat dari seluruh "stakeholder" (perusahaan, pemerintah dan seluruh masyarakat). Mengingat besarnya dampak negatif atas pertambangan batubara maka, hal ini menjadi tanggung jawab bersama. Salah satu tanggung jawab yang dapa dilakukan 


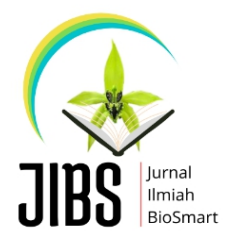

JURNAL ILMIAH BIOSMART (JIBS)

Volume 1, Nomor 1

p-ISSN: 2356-1823

https://jurnal.fkip.unmul.ac.id/index.php/biosmart

dengan menyusun dokumen analisis dampak lingkungan. hal tersebut dikuatkan oleh Wahli (2010) bahwa perlu adanya tindakan peduli terhadap lingkungan berupa: 1. Penyusunan rencana pengelolaan lingkungan; 2. Rencana pemantauan lingkungan. Kegiatan tersebut dapat menjadi program-program kepedulian terhadap lingkungan. Kegiatan tersebut guna menyadarkan seluruh lapisan masyarakat. Untuk itu, peneliti ingin analisis literasi lingkungan sebagai salah satu informasi dan bentuk kepedulian terhadap lingkungan khususnya lingkungan di Kalimantan timur.

Dampak-dampak negatif maupun positif dari pertambangan batubara menjadi masalah tersendiri yang juga harus diselesaikan dengan seksama, karena hal ini menjadi tanggung jawab semua elemen masyarakat termasuk salah satunya adalah pendidik. Tujuan pendidikan adalah membentuk pengalaman-pengalaman belajar untuk dapat merancang penyelesaian permasalahan (Anderson \& Krathwohl, 2010). Tujuan pembelajaran idealnya adalah memandu mahasiswa untuk dapat beradaptasi di dunia nyata, menjadi pemikir kritis dan kreatif, pemecah masalah, dan pengambil keputusan. Wahyana dalam Trianto (2007) menyatakan bahwa IPA didefinisikan sebagai pengetahuan yang diperoleh melalui pengumpulan data dengan eksperimen, pengamatan, dan deduksi untuk menghasilkan suatu penjelasan tentang sebuah gejala yang dapat dipercaya Sejalan dengan itu Dahar (1989) menyatakan bahwa belajar dapat membuat perubahan perilaku yang diakibatkan oleh pengalama.

Sesuai dengan dengan itu NAAEE (2011) menyatakan bahwa siswa dikatakan literate terhadap lingkungan atau melek terhadap lingkungan ketika mampu menerapkan konsep-konsep atau fakta-fakta yang didapatkan dari fenomenafenomena alam yang terjadi dalam kehidupan sehari hari. Saat ini mahasiswa memiliki kecenderungan yang menjauh dari nilai-nilai menjaga lingkungan. Kecenderungan tersebut terlihat bahwa semakin konsumtif namun kurang produktif dalam menjaga lingkungan.

Salah satu sarana untuk membangun kesadaran dan kepedulian adalah dengan adanya pendidikan lingkungan. Pendidikan lingkungan kini telah dan semakin semarak diterapkan dalam dunia pendidikan. Hal ini bertujuan untuk membangun jiwa cinta lingkungan. Dengan harapan bahwa generasi berikut menjadi generasi yang berbudaya dan memiliki kepedulian terhadap lingkungan. Sejalan dengan itu Salim 


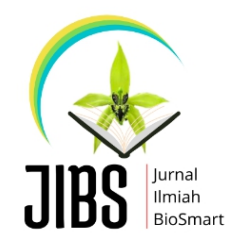

JURNAL ILMIAH BIOSMART (JIBS)

Volume 1, Nomor 1

p-ISSN: 2356-1823

https://jurnal.fkip.unmul.ac.id/index.php/biosmart

(1979) menyatakan bahwa generasi muda yang bertanggung jawab mengatasi permasalahan-permasalahan lingkungan pada bangsa ini. Pendapat tersebutlah yang menjadikan perlu adanya penelitian untuk mengetahui tinglat literasi lingkungan Mahsiswa khususnya di Kalimantan timur.

\section{A. Literasi Lingkungan}

Literasi lingkungan adalah melek lingkungan, yang meliputi berbagai pengetahuan tentang lingkungan. Melek lingkungan juga terdiri dari bagaimana cara bersikap, bertanggung jawab, peduli dan sadar akan keberadaan lingkungan. Cantrell \& Hughes (2008) menyatakan bahwa pendidikan bukan hanya tentang kurikulum tapi termasuk juga pembelajaran dan hasil dari pembelajaran serta kemampuan yang diperoleh setelah pembelajaran. Pembelajaran menjadi salah satu sarana untuk mencapai pendidikan. Salah satunya dengan pendidikan lingkungan. Sejalan dengan itu Fah \& Sirisena (2014) menyatakan bahwa pendidikan lingkungan bukan hanya pengetahuan tetapi sikap peduli juga termasuk didalamnya. Sekolah merupakan sarana untuk melakukan hal yang masuk akal ketika dipertimbangkan dalam konteks yang lebih luas. Jena (2012) menyatakan bahwa lingkungan akan menjadi diskusi penting di dunia. Sejalan dengan itu O'Brien (2007) menyatakan bahwa pengtahuan dapat meningkatkan kepedulian terhadap banyak hal. Lingkungan merupakan hal yang penting di mata dunia sehingga dampak proaktif akan memperlihatkan hasil nyata dari pemeliharaanya lingkungan itu sendiri.

Meningkatkan literasi lingkungan mahasiswa dapat dilakukan dengan berbagai cara yang salah satunya dengan adanya proses pembelajaran. Hasil penelitian menunjukkan bahwa beberapa penelitian menyebutkan bahwa literasi lingkungan dapat meningkatkan kepedulian terhadap lingkungan. Penelitian tersebut dikuatkan oleh NELA (2008) yang mengatakan bahwa peneliti mengaitkan pembelajaran dengan mengembangkan instrumen literasi lingkungan untuk mengukur penetahuan, sikap, perilaku dan keterampilan kognitif. Sejalan dengan itu Cunningham (2008) menyatakan bahwa instrumen tersebut untuk mengukur pengetahuan, sikap, perilaku dan keterampilan kognitif.

Rickinson (2001) menyatakan bahwa NAAEE (2010) dan NELA (2008) serta Chu et al., (2007) telah melakukan penelitian tentang pendidikan lingkungan yang 


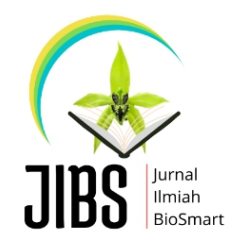

JURNAL ILMIAH BIOSMART (JIBS)

Volume 1, Nomor 1

p-ISSN: 2356-1823

https://jurnal.fkip.unmul.ac.id/index.php/biosmart

menjadi sarana untuk menggambarkan kondisi lingkungan. Dengan pendidikan lingkungan siswa dapat mengetahui lebih dalam perihal masalah yang terjadi di lingkungan. Sehingga dapat menciptakan kesadaran pada diri siswa terhadap lingkungan. Pendidikan lingkungan dapat meningkatkan literasi lingkungan siswa. Sejalan dengan itu Scholz (2011) menyatakan bahwa literasi lingkungan dapat memotivasi siswa untuk peduli terhadap lingkungannya. Hal ini akan membantu siswa dalam melestarikan lingkungan disekeliling mereka. Hal tersebut dikuatkan oleh Schmidt et al., (2013) serta Rose (2010) menyatakan juga bahwa pengetahuan dan sikap menajdi dasar dalam literasi lingkungan. Literasi lingkungan dapat menjadikan seseorang memiliki kesadaran dan kepedulian terhadap lingkungannya.

NAAEE (2011) menyatakan bahwa literasi lingkungan merupakan suatu tindakan yang didasari pada kepedulian terhadap lingkungan. Literasi lingkungan dapat dibangun dengan mempelajari keberadaan lingkungan disekitar. Literasi lingkungan harus ditingkatkan di semua elemen masyarakat. Hal ini karena literasi lingkungan dipengaruhi oleh aspek internal dan eksternal. Interasksi antar manusia dan lingkungan dapat menjadikan seseorang memiliki literasi lingkungan. hal yang juga penting ialah dengan memberikan pendidikan lingkungan. hal ini membutuhkan kerjasama dari banyak pihak, salah satunya pendidikan.

\section{Literasi lingkungan}

Lingkungan tidak berdiri sendiri sebagai bagian dari sains. Literasi lingkungan memiliki komponen dan aspek-aspek penyusun literasi lingkungan tersebut. Domaindomain tersebut merupakan bagian yang menyusun literasi lingkungan. Literasi lingkungan terdiri dari pemahaman terhadap lingkungan. Pemahaman tersebut menjadi tolak ukur dalam literasi lingkungan. literasi lingkungan merupakan suatu kesatuan dari bagian-bagian yang mendasarinya. Sejalan dengan itu NAAEE (2011) menyatakan bahwa literasi lingkungan memiliki empat doamin yaitu : (1) pengetahuan (knowledge), (2) keterampilan kognitif (cognitif skill), (3) sikap attitude (4) perilaku behavior. Berdasarkan hal tersebut lingkungan menjadi penting karena memiliki domain yang baik jika dikembangkan.

\section{Hubungan Pembelajaran Dengan Literasi Lingkungan}




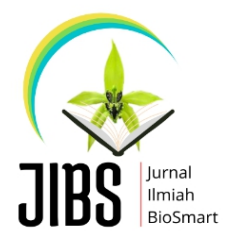

JURNAL ILMIAH BIOSMART (JIBS)

Volume 1, Nomor 1

p-ISSN: 2356-1823

https://jurnal.fkip.unmul.ac.id/index.php/biosmart

(UNESCO, 1976) dalam NAAEE (2011) menyatakan bahwa pendidikan merupakan sarana untuk meningkatkan pendidikan lingkungan. Berdasarkan hasil penelitian pendidikan lingkungan dapat meningkatkan sikap lingkungan seseorang. pendidikan lingkungan mengkaji ilmu lingkungan seperti mempelajari energi, ekosistem, bahan bakar fosil, dan humaniora. Dengan mengaitkan pendidikan dengan lingkungan sekitar maka pengetahuan isu lingkungan mengacu memahami konsep-konsep yang berkaitan dengan pengetahuan lingkungan isu spesifik dan interaksi manusia.

Berdasarkan tujuan tersebut, penbelajaran dapat menjadi sarana untuk meningkatkan pendidikan lingkungan, sehingga dapat terus dijaga. Sejalan dengan itu saat ini pembelajaran sering diintegrasikan dengan mata pelajaran lain dalam pendidikan disekolah. Pendidikan formal dalam hal ini sekolah terus berusaha menjaga dan membantu pemerintah untuk membangun kepedulian terhadap lingkungan melalui pembelajaran berbasis lingkungan. Sejalan dengan itu pemerintah sendiri telah membuat peraturan dalam pendidikan lingkungan lingkungan yakni peraturan dalam kurikulum pendidikan. Pada kurikulum 2013 pemerintah mengintegrasikan pendidikan kedalam setiap mata pelajaran. Pemerintah menginginkan terciptanya kesadaran akan lingkungan, dengan hal tersebut menajadikan pendidikan sebagai sarana untuk mencapai tujuan tersebut. Dengan hal tersebut pendidikan diharapkan dapat menjawab tantangan untuk mewujudkan generasi masa depan yang peduli terhadap lingkungan.

\section{METODE}

Metode penelitian yang digunakan dalam penelitian ini adalah metode penelitian deskriptif. Metode tersebut tidak memberikan perlakuan, manipulasi, atau pengubahan terhadap sampel yang digunakan sehingga tidak memerlukan kelas kontrol maupun kelas eksperimen (Frankel \& Hyun, 2012). Data yang dikumpulkan dianalisis dan diinterpretasi, kemudian di deskripsikan untuk menggambarkan kondisi yang terjadi pada subjek penelitian.

Menurut Sukmadinata (2011) penelitan deskriptif bertujuan mengambarkan secara sistematis dan akurat fakta dan karakteristik mengenai populasi atau mengenai bidang tertentu. Data yang dikumpulkan dianalisis dan diinterpretasi, 


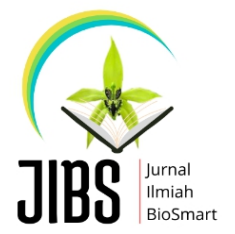

JURNAL ILMIAH BIOSMART (JIBS)

Volume 1, Nomor 1

p-ISSN: 2356-1823

https://jurnal.fkip.unmul.ac.id/index.php/biosmart

kemudian di deskripsikan untuk menggambarkan kondisi yang terjadi pada subjek penelitian.

Dalam penelitian deskriptif penelitian berusaha memotret peristiwa dan kejadian yang menjadi pusat perhatiannya, kemudian menggambarkan atau melukiskan sebagaimana adanya, sehingga pemanfaatan temuan penelitian ini berlaku pada saat itu pula. Namun hasil dari penelitian tersebut belum tentu relevan bila digunakan untuk waktu yang akan datang.

Penelitian dilakukan di FKIP Universitas Mulawarman karena fakultas keguruan dan ilmu pendidikan karena dari kampus inilah para calon guru nantinya tercipta. Populasi dalam penelitian ini adalah mahasiswa pendidikan MIPA FKIP Universitas Mulawarman Sampel pada penelitian ini adalah mahasiswa pendidikan MIPA pada kelas yang telah dipilih untuk diberikan tes literasi lingkungan.

Pengumpulan data pada penelitian ini dilakukan dengan menggunakan beberapa instrumen yang terdiri dari tes dan non test. Tes berupa soal dan non test berupa. Soal-soal yang digunakan adalah soal pilihan ganda. Soal tersebut merupakan soal liteasi lingkungan yang terdiri dari empat bagian. Dimana setiap bagiannya adalah empat domain dalam literasi lingkungan.

Tabel 1. Kisi-Kisi Soal Literasi Lingkungan

\begin{tabular}{llc}
\hline $\begin{array}{c}\text { Domain Literasi } \\
\text { Lingkungan }\end{array}$ & \multicolumn{1}{c}{ Aspek } & $\begin{array}{c}\text { Jumlah } \\
\text { Item }\end{array}$ \\
\hline & 1. $\quad \begin{array}{l}\text { Macam-macam pencemaran lingkungan (menjaga } \\
\text { lingkungan, analisis dampak lingkungan, analisis } \\
\text { perubahan lingkungan). }\end{array}$ & 20 \\
A. Pengetahuan & $\begin{array}{l}\text { 2. Penyebab pencemaran lingkungan } \\
\text { 1. Identifikasi Isu }\end{array}$ & 13 \\
\hline B. Keterampilan & $\begin{array}{l}\text { 2. Analisis Isu } \\
\text { 3. Rencana Penyelidikan Isu. }\end{array}$ & 25 \\
\hline C. Sikap & $\begin{array}{l}\text { 1. Bagaimana anda berpikir tentang lingkungan. } \\
\text { 2. Anda dan kepekaan lingkungan. }\end{array}$ & 15 \\
\hline D. Perilaku & 3ertangaimana perasaan anda terhadap lingkungan. & \\
\hline
\end{tabular}

Soal literasi lingkungan yang digunakan dalam penelitian ini akan diteskan kepada mahasiswa. Dengan demikian akan memperoleh data berupa jawabaan 


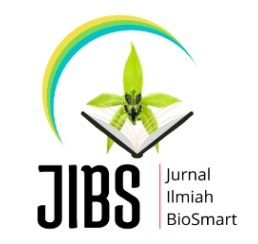

JURNAL ILMIAH BIOSMART (JIBS)

Volume 1, Nomor 1

p-ISSN: 2356-1823

https://jurnal.fkip.unmul.ac.id/index.php/biosmart

mahasiswa. Jawaban-jawaban tersebut skor menggunakan metode tranformasi skor mentah yang digunakan oleh NELA (2008).

Keterangan rentang skor dan kategori untuk tiap komponen:

Pengetahuan $\quad:$ Rentang $=0-60$, Rendah $=0-20$, Sedang 21-40, Tinggi $=41-60$.

Sikap $\quad:$ Rentang $=15-60$, Rendah $=15-30$, Sedang 31-45, Tinggi $=46-$

60.

Keterampilan Kognitif $:$ Rentang $=0-60$, Rendah $=0-20$, Sedang 21-40, Tinggi $=41-60$.

Perilaku $\quad:$ Rentang $=12-60$, Rendah $=12-27$, Sedang $28-44$, Tinggi $=45-$ 60.

Literasi Lingkungan $\quad:$ Rentang $=27-240$, Rendah $=27-98$, Sedang 99-169, Tinggi $=$ 170-240.

Observasi kelas dilakukan untuk mendapatkan data menyeluruh tentang proses pembelajaran. Observasi yang dilakukan berkaitan dengan penjaringan data untuk mengukur literasi lingkungan mahasiswa. Hal ini menjadi penting karena dengan mengobservasi pembelajaran telah mendukung untuk mengembangkan literasi lingkungan mahasiswa.

Setelah penelitian selesai dilakukan, di peroleh data. Data tersebut diolah dan di simpulkan untuk mengetahui ketercapaian dari literasi lingkungan. Analisis jawaban soal literasi lingkungan Analisis data pada tahap ini dilakukan setelah selesai mengumpulkan data di lapangan. Penilaian jawaban siswa dicocokkan berdasarkan pensekoran literasi lingkungan. Sedangkan untuk mengolahan data mengunakan rumus $\mathrm{NP}=\mathrm{R} / \mathrm{SM} \times 100 \%$.

\section{HASIL DAN PEMBAHASAN}

Data yang diperoleh dalam penelitian ini dikumpulkan melalui hasil jawaban tes literasi lingkungan. Data hasil penyelesaian soal yang terkumpul kemudian dianalisis dan disajikan dalam bentuk data statistik inferensial. Soal literasi lingkungan yang disusun peneliti memuat empat domain dalam literasi lingkungan yaitu pengetahuan, kemampuan kognitif, sikap dan perilaku. Pengolahan data menggunakan perhitungan sederhana menggunakan Microsoft Exel 2007. 
Hasil analisis jawaban yang memuat empat domain literasi lingkungan tercantum pada. Gambar dibawah, pada gambar memperlihatkan secara umum kemampuan literasi lingkungan mahasiswa pendidikan MIPA FKIP Universitas Mulawarman.

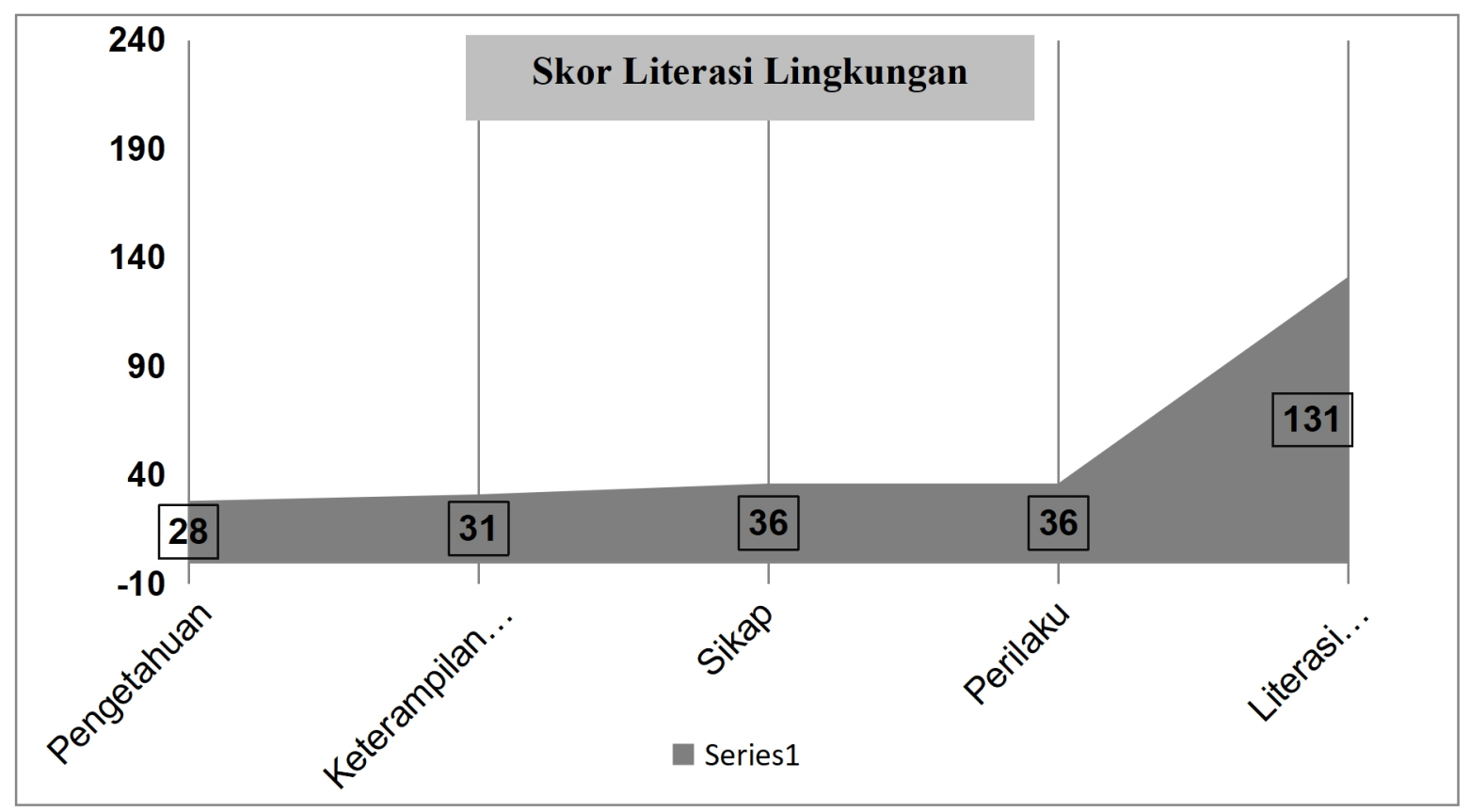

Gambar. Skor tes literasi lingkungan dan rincian per domain

Gambar diatas menunjukkan bahwa secara umum kemampuan literasi lingkungan yang diperoleh mahasiswa pendidikan MIPA FKIP Universitas Mulawarman pada setiap domain memiliki kategori sedang. Kategori tersebut dilihat dari perolehan skor 131, dapat dikategorikan "Sedang".

Hasil kemampuan literasi lingkungan yang masuk dalam kategori sedang diperoleh dari skor gabungan setiap domain dalam literasi lingkungan. Skor gabungan tersebut dikalkulasikan menjadi satu, sehingga dapat diketahui hasil literasi lingkungan yang diinginkan oleh peneliti. Berdasarkan hasil jawaban tes dapat diketahui bahwa mahasiswa melek lingkungan. Domain-domain dalam literasi lingkungan diukur untuk dapat menggambarkan literasi lingkungan mahasiswa. sesuai dengan yang dikatakann oleh Cantrell (2008) bahwa melek lingkungan dengan 


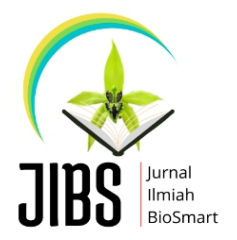

JURNAL ILMIAH BIOSMART (JIBS)

Volume 1, Nomor 1

p-ISSN: 2356-1823

https://jurnal.fkip.unmul.ac.id/index.php/biosmart

bersikap, bertanggung jawab, peduli dan sadar akan keberadaan lingkungan. Hasil tes yang telah dianalisis sehingga dapat diketahui bahwa mahasiswa melek lingkungan. Dengan kata lain mahasiswa berliterasi terhadap lingkungan. Hal ini diketahui dari perolehan skor yang dideskripsikan kedalam kategori capaian. Kategori capaian yang diperoleh ialah kategori sedang. Pada dasarnya perolehan kategori tersebut melalui beberapa tahapan, dimana peneliti memulai dengan melakukan pensekoran jawaban tes. Dari data tersebut ditabulasikan menjadi angka-angka dan di peroleh skor literasi lingkungan.

Berkenaan dengan analisis literasi lingkungan yang dilakukan oleh peneliti telah diketahui bahwa mahsiswa memiliki literasi lingkungan yang sedang. Hal berarti bahwa mahasiswa memiliki kesadaran dan keperdulian terhadap lingkungan, namun tidak pada level yang tinggi. Sejalan dengan pendapat UNESCO dalam NAAEE (2008) yang menyatakan bahwa pendidikan lingkungan dapat meningkatkan sikap lingkungan seseorang. Hal tersebut dikuatkan oleh peneliti terdahulu bahwa pendidikan dapat menjadikan mahasiswa berliterasi lingkungan. Proses pembelajaran merupakan sarana untuk meningkatkan pemahaman mahasiswa terhadap lingkungan. Materi-materi dan matakuliah yang berkaitan dengan lingkungan sangat membantu untuk membangun serta meningkatkan level literasi mahasiswa.

Penelitian yang dilakukan pada mahasiswa FKIP khususnya pada mahasiswa pendidikan MIPA bertujuan untuk mengetahui level awal pada level literasi lingkungan. Hal ini berkaitan dengan kepedulian penelitian untuk terus membantu pemerintah untuk meningkatkan kesadaran serta pemahaman siswa maupun mahasiswa terhadap lingkungan. Kurikulum yang digunakan oleh universitas Mulawarman sangat menekankan pembelajaran dikaitkan dengan Stopical Studies yang bermakna bahwa setiap pembelajaran maupun proses pembentukan pengetahuan selalu berpegangan pada tema besar yang dijadikan Universitas sebagai dasar Visi untuk lebih maju serta bersinergi dengan lingkungan disekiar kita khususnya di Kalimantan Timur yang memiliki sumberdaya alam yang berlimpah serta hutan tropis yang luas. Hal itu diharapkan dapat menjawab tantangan untuk mewujudkan generasi masa depan yang memiliki literasi lingkungan dan perduli terhadap lingkungan. 


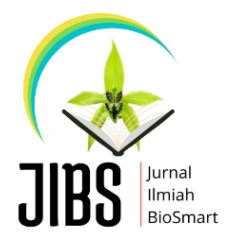

JURNAL ILMIAH BIOSMART (JIBS)

Volume 1, Nomor 1

p-ISSN: 2356-1823

https://jurnal.fkip.unmul.ac.id/index.php/biosmart

Pembelajaran juga sebagai alat untuk mencapai pendidikan yang diharapkan. Bahkan nilai-nilai tersebut ada dalam setiap jenjang pendidikan. Hal ini terlihat dalam standar kompetensi lulusan untuk jenjang sekolah dasar hingga perguruan tinggi secara eksplisit mencantumkan bahwa peserta didik dituntut untuk memiliki perilaku yang mencerminkan sikap orang beriman, berakhlak mulia, percaya diri, dan bertanggung jawab dalam berinteraksi secara efektif dengan lingkungan sosial dan alam. sehingga dapat dikatakan bahwa pendidikan lingkungan sangat penting dalam kehidupan.

Pendidikan merupakan sarana penting bagi kehidupan manusia karena menjadi kebutuhan pokok bagi seluruh lapisan masyarakat. Menurut Undang-Undang Nomor 20 Tahun 2003 tentang Sistem Pendidikan Nasional menyatakan "pendidikan adalah usaha sadar dan terencana untuk mewujudkan suasana belajar dan proses pembelajaran peserta didik secara aktif untuk mengembangkan potensi dirinya". Selain itu, "pendidikan nasional berfungsi mengembangkan kemampuan dan membentuk watak serta peradaban bangsa yang bermartabat dalam rangka mencerdaskan kehidupan bangsa, bertujuan untuk berkembangnya potensi peserta didik agar menjadi manusia yang beriman dan bertakwa kepada Tuhan Yang Maha Esa, berakhlak mulia, sehat, berilmu, cakap, kreatif, mandiri dan menjadi warga negara yang demokratis serta bertanggung jawab.

Kepedulian mahasiswa terhadap lingkungan tidak hanya menjadi tanggung jawab dirinya namun juga lingkungan akademik disekelilingnya dimana dia menuntut ilmu. Ketika mahasiswa memiliki pengetahuan tentan lingkungan hal itu juga akan membentuk karakter yang baik terhadap lingkungan serta akan lebih perduli dengan keadaaan lingkungan disekitarnya. Penanaman nilai peduli lingkungan dapat dilakukan dengan cara yang salah satunya dengan membuat mahasiswa dapat berpikir kritis terhadap lingkungan. Hal terebut dapat mendukung pembetukan keterampilan kognitif siswa dimana, keterampilan kognitif juga merupada salah satu domain dalam literasi lingkungan. Hal ini tidak hanya penting bagi mahasiswa tapi juga dapat membuat siswa berpikir serta bertindak sesuai kesadaran tinggi terhadap lingkungan. Kegiatan-kegiatan yang berkaitan dengan lingkungan dapat 


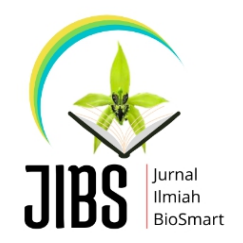

JURNAL ILMIAH BIOSMART (JIBS)

Volume 1, Nomor 1

p-ISSN: 2356-1823

https://jurnal.fkip.unmul.ac.id/index.php/biosmart

memingkatkan perilaku positif terhadap lingkungan. Dengan demikian dapat dikatan bahwa siswa melek serta sadar terhadap lingkungannya.

Kesadaran yang ditimbulkan dari pendidikan baik dalam proses pembelajaran maupun dari perilaku akademik mahasiswa pada lingkungan dapat membuat mahasiswa melek lingkungan atau memiliki literasi lingkungan. Berdasarkan hal tersebut peneliti ingin menjadikan penelitian ini sebagai sarana menginformasikan perlunya memiliki literasi lingkungan pada diri masyarakat khususnya mahasiswa. Dengan demikian ketercapaian tentang keperdulian pada lingkungan menjadi informasi yang harus disebar luarkan, sebagai pandangan dalam membuat kurikulum terkait dengan lingkungan. Selanjutnya, untuk mengetahui capaian pada setiap domain dalam literasi lingkungan, peneliti menjabarkan satu persatu capaian setiap domainnya.

\section{KESIMPULAN}

Hasil penelitian menunjukkan bahwa kemampuan literasi lingkungan mahasiswa pendidikan MIPA pada fakultas keguruan dan ilmu pendidikan Universitas Mulawarman masuk dalam katagori sedang dengan skor 131. Literasi lingkungan yang diukur juga meliputi domain-domain yang termasuk dalam literasi lingkungan. Tes literasi lingkungan dilakukan satu tes sebagai acuan level liteasi lingkungan. Domain pertama adalah pengetahuan, berdasarkan hasil tes diketahui bahwa skor yang dimiliki oleh mahasiswa dalam domain ini adalah sedang. domain kedua adalah keterampilan kognitif, dimana dalam domain ini hasil tes menunjukkan bahwa mahasiswa juga masuk dalam karagori sedang. Dalam domain sikap dalam literasi lingkungan terdapat tiga aspek yang juga ikut diukur dalam soal yaitu: berpikir tentang lingkungan; kepekaan terhadap lingkungan; perasaan terhadap lingkungan. Aspek-aspek tersebut dapat menggambarkan sikap mahasiswa dalam literasi lingkungan, sedang domain keempat ialah perilaku bertanggung jawab terhadap lingkungan. Hasil dari tes literasi dalam domain perilaku diketahui bahwa perilaku mahasiswa masuk dalam katagori sedang dan sedang. Berdasarkan hasil test yang dilakukan diketahui bahwa secara keseluruhan dapat dinyatakan bahwa test mahasiswa masuk pada katagori sedang. 


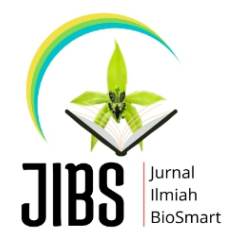

JURNAL ILMIAH BIOSMART (JIBS)

Volume 1, Nomor 1

p-ISSN: 2356-1823

https://jurnal.fkip.unmul.ac.id/index.php/biosmart

\section{UCAPAN TERIMA KASIH}

Penelti mengucapkan terimakah kepada fakultas keguruan dan ilmu Pendidikan yang telah memberikan kesempatan kepada peneliti dapat lolos dalam hibah penetian FKIP Universitas Mulawarman tahun 2019 dan menjadi sumber pendanaan dalam penelitian ini.

\section{REFERENSI}

Anderson \& Krathwohl. (2010). Kerangka landasan untuk pembelajaran, pengajaran, dan asesmen. Pustaka pelajar.

Cantrell, S. C. \& Hughes, H. K. (2008). Teacher Efficacy and Content Literacy Implementation: An Exploration of the Effects of Extended Professional Development with Coaching. Journal of Literacy Research. ISSN: 1086 296X print/1554-8430 online. University of Kentucky Collaborative Center for Literacy and Development.

Cunningham Denise, D. (2008). Literacy Environment Quality in Preschool and Children's Attitudes Toward Reading and Writing. Literacy Teaching and Learning Volume 12, Number 2 • Spring 2008.

Dahar Ratna Wilis. (1989). Teori-Teori Belajar. Erlangga.

Fah Lay Yoon \& Sirisena Anuthra. (2014). Relationships Between The Knowledge, Attitudes, And Behaviour Dimensions Of Environmental Literacy: A Structural Equation Modeling Approach Using Smartpls. Universiti Malaysia Sabah, 2SMK Chung Hwa, Tenom. Jurnal Pemikir Pendidikan (Journal for Educational Thinkers). Vol. 5, pp. 119-144, ISSN 1985-3637.

Frankel, J. R. Wallen N. E. \& Hyun, H. H. (2012). How to Desigen and Evaluate Reserch in Education. New York : McGraw-Hill.

Jena, A. K. (2012). Awareness, Openness and Eco-friendly (AOE) Model Teaches Preservice Teachers on How to be Eco-friendly. Assam University, India. International Electronic Journal of Environmental Education. Vol.2, Issue 2, 2012, $103-117$.

NELA. (2008). National Environmental Literacy Assessment. Sub. Environment education Division Grant\#NAo6SEC4690009.

(NAAEE) by the North American Association for Environmental Education (2011). Washington, USA. Diakses dari: http://www.naaee.net/. 


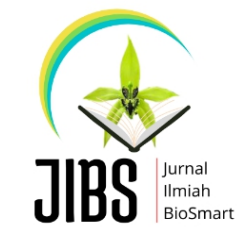

JURNAL ILMIAH BIOSMART (JIBS)

Volume 1, Nomor 1

p-ISSN: 2356-1823

https://jurnal.fkip.unmul.ac.id/index.php/biosmart

O'Brien Susan Roberta Mello. (2007). Indications of environmental literacy: using a new survey instrument to measure awareness, knowledge, and atttudes of university-aged students. lowa State University. Follow this and additional works at: $h t t: / / l i b . d r . i a s t a t e . e d u / r t d$.

Raven, P. H. et al. (2013). Environment. University of Maryland, College Park St. Peterburg College. VOL. 1, NO. 12, SEPTEMBER 2013, jmk.17.2.

Rose, M. A. (2010). Enhancing Environmental Literacy and Technology Assessment Skills. Journal of Technology Education Vol. 22 No. 1, Fall 2010 -43.

Salim, E. (1979). Lingkungan Hidup dan Pembangunan. Jakarta : Mutiara.

Schmidt et al. (2013). Science Education In Out-Of-School Contexts. Environmental, health and outdoor science education Strand. (Thesis). University of Kassel, Germany. Dortmund University, Germany.

Sukmadinata Nana Syaodih. (2011). Metode Penelitian Pendidikan. Bandung: PT Remaja Rosdakarya.

Trianto. (2007). Model-Model Pembelajaran Inovatif Berorientasi Konstruktivistik. Prestasi Pustaka.

Wahli. (2010). Batubara mematikan Bagaimana rakyat Indonesia membayar mahal untuk bahanbakar terkotor di dunia Greenpeace adalah organisasi kampanye global yang bertindak. Greenpeace Asia tenggara. E-book Diakses dari : www. Greenpeace.org/seasia. 